\title{
CLASH OF POWER AND CREED: CULTURAL (RE)FOUNDATIONS IN NORTHWEST AFRICA
}

\author{
Jorge Correia
}

In 1415, the prestigious conquest of the Muslim stronghold of Ceuta, strategically positioned between the Mediterranean Sea and the Atlantic Ocean, was the beginning of the overseas expansion of Portugal. The Portuguese were to remain in Northwest Africa for more than three centuries, until they abandoned Mazagão in 1769 [Map 3].

Despite their long presence in the area, the Portuguese were never able to establish a permanent access to the hinterland beyond the limits of the walls of their cities, especially in the southern territory. Occasionally, peace treaties or alliances allowed the Portuguese to extend temporarily their administrative influence, but in general their cities remained isolated. Portuguese Ceuta, for example, stood alone for more than four decades, prey to incessant raids from Fes and hostage to the ambition of the Portuguese crown to conquer its neighbour Tangier for the Christian cause. This enterprise would turn into a catastrophy in 1437, when the king's brother, Don Fernando, was captured. ${ }^{1}$ From that moment, the interest of the Portuguese in North Africa diminished somewhat, given the coeval discoveries of the Madeira and Azores isles and the discovery of a passable route around Cape Boujdour in 1434 by the Portuguese mariner Gil Eanes.

Only in 1458, Don Afonso V restored the image of a Christian overseas reconquista through the capture of Qsar es-Seghir, fostering a parallel process of conquests and discoveries on the African continent. The new strategy relied on the taking of Asilah, a smaller town on the Atlantic shore. When it fell in Christian hands in 1471, it became possible to besiege Tangier from land. Only four days after the capture of Asilah, the victorious Portuguese king entered the long coveted city, deserted and abandoned by its population. Afonso's display of power compelled the king of Fes to sign a twenty-year truce, renewable for

\footnotetext{
${ }^{1}$ About this episode: Oliveira Marques A.H. (ed.), Nova História da Expansão Portuguesa. A Expansão Quatrocentista (Lisbon: 1998) vol. II 256-268.
} 

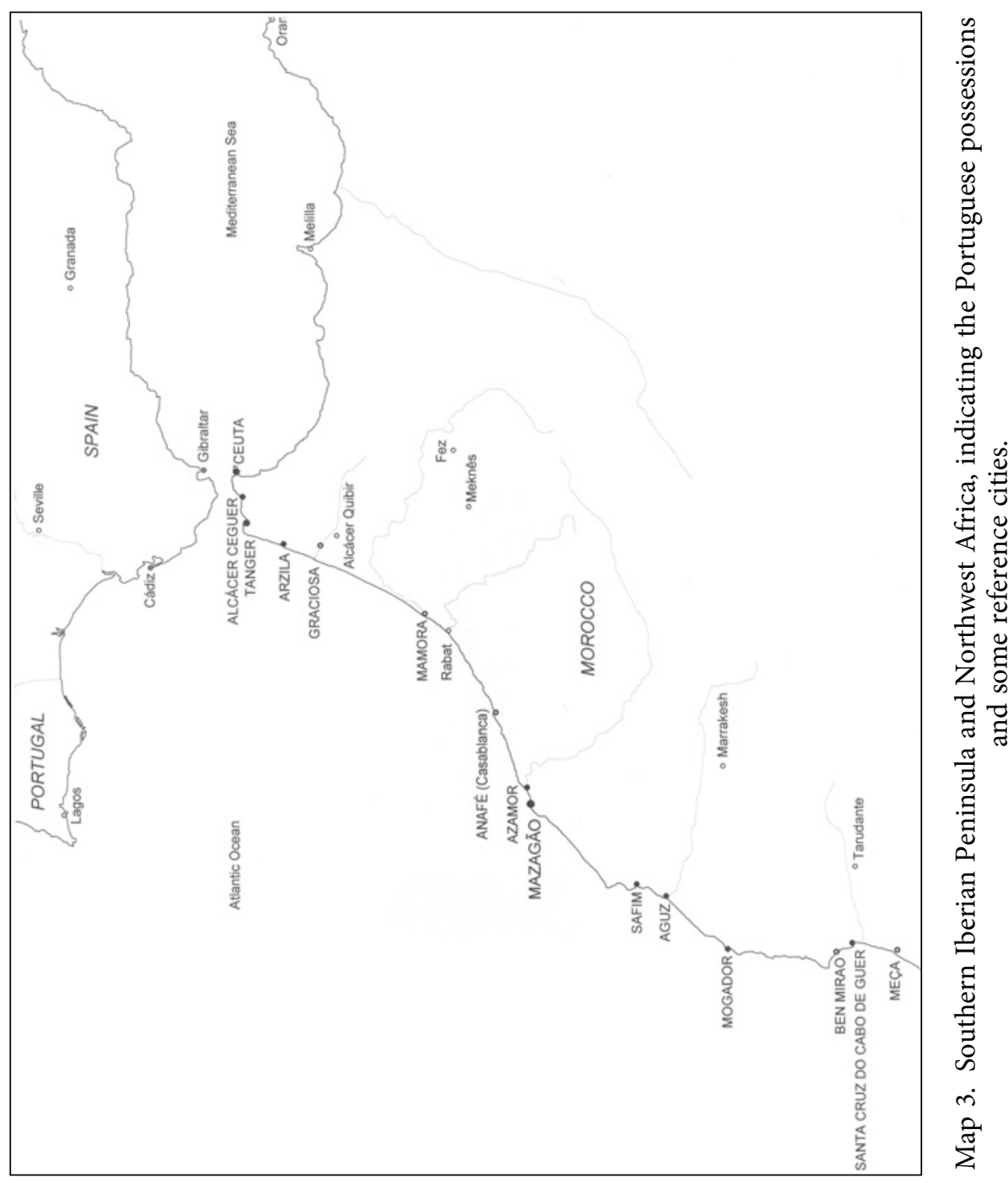
another ten. ${ }^{2}$ With this victory, Portugal had become one of the kingdoms that disputed the Western Mediterranean, along with Castile, Granada and Fes.

The year 1471 also marked the end of the slow agony of the Marinid dynasty and the emergence of the Wattasid rulers in Fes. ${ }^{3}$ Meanwhile, a new dynasty that traced its origins back to the prophet Mohammed, the Saadis, emerged from the South. Their creation of a new capital in Morocco, today's Marrakech, led to a political polarization of the western Maghreb. The Portuguese were able to exploit this instable situation by means of an ingenious protocol management vis à vis its territorial and commercial interests in the region. The Portuguese were allowed to install trading posts in a number of Muslim towns located in the South, such as Azemmour (1486) or Safi (1488), in turn of military protection. When these cities demanded suzerainty, they were eventually taken over with military means.

In this period, the Portuguese navigator Bartolomeu Dias sailed round the Cape of Good Hope, opening the way to the Indian Ocean and to the establishment of Ormuz, Goa and Melaka, bringing the trading triangle of the most important spice sea routes under Portuguese control. ${ }^{4}$ The entrepreneurs on the new route founded fortresses in strategic places on both the West and the East shores of Africa. Attempts were made to copy this successful strategy in the Maghreb. ${ }^{5}$ Yet, the military successes of the Portuguese in Northwest Africa alternated with defeats, of which the Tangier episode of 1437 was merely the first. In fact, although less frequently adopted, the Portuguese employed another paradigmatic strategy to establish cities on the Atlantic coast of North Africa, namely the foundation of new towns. This alternative approach of the territory, seeking strategic points of implantation, turned out less fortunate for the Portuguese crown. New fortified

\footnotetext{
${ }^{2}$ Guevara A.L., Arcila durante la ocupación Portuguesa (1471-1549) (Tangier: 1940) 28.

${ }^{3}$ Métalsi M. - Treal C. - Ruiz J.-M., Les villes impériales du Maroc (Paris: 1999) $30-31$.

${ }^{4}$ Boxer C.R., O Império Marítimo Português, 1415-1825 (Lisbon: 2001) 62.

${ }^{5}$ After the signing of the Treaty of Tordesillas in 1494, by which Portugal and Spain divided the newly discovered lands outside of Europe among themselves, the crusade against the kingdom of Fes was divided in two at the Ceuta isthmus. The western part fell under the sovereignty of Portugal, while to the East the way was open for the Catholic kings to conquer and settle in the Mediterranean Maghreb once Granada had been defeated. The Spanish conquests of Melilla (1497) and Oran (1509) are the symbols of yet another political power in the military equation of North Africa.
} 
positions in geographically relevant sites resulted in an ephemeral pulverisation of the Portuguese presence on the North African coast. Frequent military raids from local hostile tribes often meant an early end to these new foundations. Since the Portuguese remains of Agadir (former Santa Cruz do Cabo de Guer) were completely destroyed in the earthquake of 1960, the only successful foundation fortress-city to remain today is Mazagão, built from 1541 onwards.

Thus, even if the history of Portuguese conquests, foundations and retreats in this territory lasted more than three and a half centuries, by the beginning of the sixteenth century a pattern of Portuguese settlements had been established, consisting of Qsar es-Seghir (1458) and Tangier (1471) together with Ceuta along the Strait of Gibraltar, Asilah (1471), also in the northern extremity though already on the Atlantic shore, and later Safi (1508) and Azemmour (1513), further south on the coast of present-day Morocco.

The occupations lasted long enough to allow the Portuguese to transform some pre-existing Islamic cities; the Portuguese occupation of Safi and Azemmour would last until 1542, those of Qsar es-Seghir and Asilah until 1550. Conquest was the preferred modus operandi of the Portuguese crown in this territory. This model of settlement stimulated the adoption of European urban models incorporating an Islamic matrix, built by Portuguese lords in cities devoid of their indegenous population, and visible especially in the military architecture and the public buildings and spaces. Therefore, the arrival of a new power and creed in the Mahreb implied both a re-evaluation of the existing urban space and the desire to break with previous European models. After all, this was a time when the establishment of medieval new towns and the renovating hygienist spirit in Europe altered conceptions of the city and announced a budding modernity.

This development came to a sudden end with the loss of Santa Cruz do Cabo de Guer to the ascendant Saadi Cherif in 1541. The first loss of Portuguese settlement after a military defeat greatly distressed Don João III and his court, leading to a renewed discussion about Portuguese presence in the Maghreb. ${ }^{6}$ The king decided to give up most Portuguese possessions in the region. Only three citadels were

\footnotetext{
${ }^{6}$ This issue was being raised from the biennium of 1534-35, during which the king's council and clergy were asked by the crown to maintain or evacuate the North African town fortresses. See for the replies of 1534 Cénival P., Les Sources Inédites de l'Histoire du Maroc (Paris: 1946), vol. II, Deuxième Partie 637-703; for those of 1535,
} 
kept: Ceuta and Tangier, the largest and most important strongholds, and Mazagão, which had been founded only recently. ${ }^{7}$

The decision of Don João III to reduce his presence in the area was undoubtedly motivated by the threat of the Saadi Muslim political current. The reduction of the Christian presence in the area required a concomittant adoption of modern military techniques and defence architecture. Muslim threats came now both from land and from sea, since the Turkish navy was expanding its influence into the Western Mediterranean. From this point on, Portugal's strategy in the Western Mediterranean was motivated both by the commercial benefits from Saharan caravans arriving at the ports of Morocco and Fes with products from the Maghreb, and by the political prestige bestowed by victories over the Muslims as will be discussed below.

In Ceuta, Tangier and Mazagão (today El Jadida), a long-lasting Muslim stratum has been alternated with shorter Christian episodes. In each case, the Portuguese interval had a decisive influence on the urban fabric, and its alternation with Muslim or other European phases (such as the brief British presence in Tangier, or the ongoing Spanish presence in Ceuta) is a trace of the interaction between politics and religion in the region: be it the Muslim-Christian situation of Ceuta, the Christian-Muslim phases of El Jadida, or the Muslim-ChristianMuslim history of Tangier. But, beyond the alternation in creed, at the root of the greed and disputes over these cities were also profound cultural traditions.

\section{The Mythological Origins of Ceuta and Tangier}

Upon the arrival of the Portuguese, the Muslim bastions Ceuta and Tangier were the largest cities on the south side of the Strait of Gibraltar and therefore of great strategic importance. At the same time, the legendary ancient past of these cities turned them into easily recognizable symbols of power and glory. In fact, several references in classical

see Ricard R., Les Sources Inédites de l'Histoire du Maroc, Première Série - Dynastie Sa'dienne, Archives et Bibliothèques de Portugal (Paris: 1948) vol. III, 1-14, 18-21.

${ }^{7}$ Although it represents an epistemological break with preceding military architecture, it is important to remark that the motivation for the layout of Mazagão is a compromise with the (still) urban tradition developed in the examples of occupation by conquest. This is a topic that goes beyond the purposes of this article. 
works testified to their greatness and symbolical connotation. This aura was very much present in the fifteenth-century imagination, rendering the possession of these cities all the more desirable. Their conquest by the Portuguese turned Don João I in 1415 and Don Afonso V in 1471 in 'emperors' or 'princes of the Reconquest', and both kings were aware of the fame that came with the acquisition of these territories.

Across the centuries, the city of Ceuta had been as much a source of inspiration to poets, geographers and travellers alike, as an object of greed for neighbours and enemies. The reference to Ceuta in Dante's Divina Commedia is therefore no isolated instance. ${ }^{8}$ The location of Ceuta on Mount Acho was traditionally identified with one of the mythical Pillars of Hercules, that together with its European counterpart, the Rock of Gibraltar, joins two continents and guards over two seas. Circulating among several classical authors, the story was told in great detail in Pomponius Mela's De Chorographia. ${ }^{9}$ Back then, Abila (Ceuta) and Calpe (Gibraltar) had formed the gate of the ocean, separating the immensity of water from the confined Mediterranean Sea. Neither Mount Acho nor Abila gave the site its name, but yet another mountain chain called Djebel Moussa, which emerges further west, separating the peninsula from the rest of the African mainland. Its seven elevations, called Septem Frates by the ancient authors, consisted of seven hills with a similar altitude. ${ }^{10}$

Apart from these classical references, there was also a biblical source for Ceuta's topology. According to a Jewish tradition, then disseminated across the Muslim world, Ceuta would indeed have been founded

${ }^{8}$ Dante Alighieri, Inferno, XXVI, 103-111: 'L'un lito e l'altro vidi infin la Spagna, / fin nel Morrocco, e l'isola de' Sardi, / e l'altre che quel mare intorno bagna. / Io e' compagni eravam vecchi e tardi / quando venimmo a quella foce stretta/ dov'Ercule segnò li suoi riguardi / acciò che l'uom piú oltre non si metta; / da la man destra mi lasciai Sibilia / da l'altra giá m'avea lasciata Setta'.

9 Pliny The Elder, Naturalis Historia V, 2; Pomponius Mela, De Chorographia I, 23: 'Deinde est mons praealtus, ei quem ex adverso Hispania adtollit obiectus: hunc Abilam, illum Calpen vocant, Columnas Herculis utrumque. Addit fama nominis fabulam, Herculem ipsum iunctos olim perpetuo iugo diremisse colles, atque ita exclusum antea mole montium oceanum ad quae nunc inundat admissum. Hic iam mare latius funditur, submotasque vastius terras magno impetu inflectit'.

${ }^{10}$ Mentioned by Mela, De Chorographia I, 24, it is better described in Pliny's Naturalis Historia V, 18: 'Ipsa provincia ab oriente montuosa fert elephantos, in Abila quoque monte et quos Septem Fratres a simili altitudine appellant. Freto imminent iuncti Abilae'. 
by Sem, the elder son of Noah, 230 years before the Great Deluge. ${ }^{11}$ Generating many misunderstandings about the names and dates that could be inferred from the Book of Genesis, this identification led to the historically unsustainable claim that Ceuta was the oldest city in the world. ${ }^{12}$ Later, Arab geographers examined the descriptions and assessments of the site with new rigor and proposed a more accurate vision of the city and its history before the Portuguese conquest. Still, if this new vision rejected much of the mythology, the legendary origins of Ceuta remained an important motivation for several conquests, including those of the Portuguese.

The same is true for Tangier. Strategically situated, the mythological roots of the city are described by Roman authors at a time when it served as capital of the Roman province of Mauritania Tingitana, an area that corresponds approximately to Northwest Africa today. Already in the Greek period, this area had earned the designation of Ampelusia because of its proximity to a cape, known today as Spartel, the site of Hercules' mythical cave. Both Pliny the Elder in his Naturalis Historia and Pomponius Mela in De Chorographia had instead attributed the foundation of Tangier to the giant Antaeus, who had fought Hercules in Lixus, where the Garden of the Hesperides was situated. ${ }^{13}$ Soon after, under Roman domination, the name of Antaeus' widow Tinge was adopted to name the place Tingis. ${ }^{14}$ Thus, the mythological origin of Tangier had been established, and with that its status as a regional urban nucleus.

One would need to move forward in time to the transition from the early to the late Middle Ages and, with the help of short descriptions made by Arab geographers, ${ }^{15}$ attempt a more formal approach to the Islamic image of the city inherited by the Portuguese, to understand how the appetite for its possession can also be translated into a symbolic urban regeneration.

\footnotetext{
${ }^{11}$ Baeza Herratzi A., "La Fundación de Ceuta y la Fábula de Noé”, in Ripoll Perelló E. (ed.), Actas del Congreso Internacional "El Estrecho de Gibraltar" (Ceuta: 1987 Madrid: 1988) vol. II, 678.

${ }_{12}$ See Baeza Herratzi, "La Fundación de Ceuta" 674-676.

13 Pliny, Naturalis Historia V, 3. The ruins of Lixus are located on the northern shore of the mouth of the river Loukos, opposite the present city of Larache.

${ }_{14}$ Plutarch, Lives, "The Life of Sertorius" 9.

15 Al Ansari, "La physionomie monumentale de Ceuta: un hommage nostalgique à la ville par un de ses fils, Muhammad B. Al-Qasim Al Ansari", Hespéris-Tamuda 20-21 (1982-1983) 113-162.
} 
Even if the political division between the coasts of the Atlantic Iberian Peninsula and Northwest Africa became more pronounced over time, contacts by sea had been frequent since Antiquity. Therefore, the Portuguese must have been familiar with the way these cities previously had presented themselves. From 1249 onwards, with the conquest of the Algarve, Portugal conducted ever more frequent sea-raids along the African coasts in search of fishing resources or opportunities for piracy. At the same time, others ventured in this region as well, as illustrated by the Italian ventures along the coast to Safi since the mid-thirteenth century or the dispute over the Canary Islands during the fourteenth and fifteenth centuries. These circumstances contributed significantly to the topographical information and to the sailing expertise available to the Portuguese. Therefore, the capture of Ceuta in 1415 is to be understood as the transposition of a religious conflict from Iberia to the Maghreb underpinned by both strategic and symbolical motives; and not as an isolated adventure.

\section{The Christian Consecration and Adaptation of Mosques}

Ceuta was captured on 21 August 1415 after a tripartite assault led by Don João I and his three sons Duarte, Pedro and Henrique. From theories suggested by the coeval Livro dos Arautos and the Crónica da Tomada de Ceuta ['Chronicle of the Conquest of Ceuta'] ${ }^{16}$ to more recent assumptions, many reasons were adduced to explain the conquest of that city. Among inventions about the rich resources of grain in the city's surroundings and speculations about the access to yet unknown Christian worlds, one must register aspects of nobility or military enthusiasm, commercial strategy, religious fervour and attempts of the recently established Avis dynasty, which tried to cover up its 'illegitimate' origins. ${ }^{17}$

As the chronicles make clear, the investiture of the royal princes as knights by Don João I is among the most famous and applauded

\footnotetext{
${ }^{16}$ Livro dos Arautos = De Ministerio Armorum, ed. A.A. do Nascimento (Lisbon: 1977); Gomes Eanes de Zurara, Crónica da Tomada de Ceuta, ed. F.M.E. Pereira (Lisbon: 1915) and Gomes Eanes de Zurara, Crónica da Tomada de Ceuta, ed. A. Pimenta (Lisbon: 1942).

${ }_{17}$ Cf. Braga I.D. - Braga P.D., Ceuta Portuguesa 1415-1656 (Ceuta: 1998) 27-32 and Bethencourt F. - Chaudhuri K. (eds.), História da Expansão portuguesa (Lisbon: 1998) vol. I, 120.
} 
episodes of this first conquest. The royal chronicler Zurara dedicated an entire chapter of his Chronica de El-Rei D. João I to this event. ${ }^{18}$ Citing classical precedents, his words extol the virtue of fighting the 'infidels' and the honour acquired by their defeat. ${ }^{19} \mathrm{In}$ an allusion to the eternal capacity of such acts to amaze the world, the text recalled how ancient philosophers preached a similar level of glory. ${ }^{20}$

The investiture constitutes one of the most rhetorical acts of the change of epistemology that was about to transform Islamic urban areas into Christian bastions. Tellingly, it took place in the main mosques of the cities, which had just been consecrated as churches. Both the chronicle mentioned above and the Crónica da Tomada de Ceuta by Zurara cover the dedication and consecration of Ceuta's former mosque. ${ }^{21}$ Assisted by clergymen dressed in their best garments, who had travelled on the ships of Portuguese army, the main priest blessed the building with aspersions of water and salt. All walls of the mosque were sprinkled with Holy water, beginning with the east wall the qibla wall, facing Mecca. After prayers, a newly fabricated altar was set up, and it was blessed with aspersions of Holy water in the sign of the Cross. The words 'This is the house of the Lord God [...]' consecrated the former Muslim building as a Christian church. ${ }^{22}$ Finally, the altar was covered with delicate white cloth and a Te Deum Laudamus was sung accompanied by the sound of trumpets.

This ceremony would be repeated in all cities conquered by the Portuguese in the Maghreb, as for instance Qsar es-Seghir. ${ }^{23}$ Here, too, the installation of a new altar in the mosque provided the building with

\footnotetext{
${ }_{18}$ Gomes Eanes de Zurara, Chronica de El-Rei D. João I (Lisbon: 1899-1900) vol. III, chapt. 95.

${ }^{19}$ Ibidem vol. III, chapt. 94.

${ }^{20}$ Ibidem.

${ }^{21}$ Zurara, Crónica da tomada de Ceuta 90-91. See Brásio A., "A primitiva catedral de Ceuta", in História e Missiologia. Inéditos e Esparsos (Luanda: 1973) 56-83.

${ }_{22}$ Zurara, Crónica de El-Rei D. João I, vol. III, 91-92: 'Esta é a casa d Senhor Deus, a qual é bem fundada sobre firme pera, levante-se o senhor e destrua os seus inimigos por tal que fujam todos aquelles que aborrecem a sua face, dizendo ainda, a minha casa se chamará de oração, recontarei o teu nome aos meus irmãos, no meu da tua egreja te louvarei'.

${ }^{23}$ There are three main chronicles regarding the Portuguese establishment in Qsar es-Seghir: Ruit de Pina, Chronica d'El-Rei D. Affonso V (Lisbon: 1901); Gomes Eanes de Zurara, Crónica do Conde D. Duarte de Meneses, ed. L. King (Lisbon: 1978) and Damião de Góis, Crónica do Príncipe D. João, ed. G.A. Rodrigues, Universidade Nova de Lisboa (Lisbon: 1977).
} 
the essential prerogative for the Mass of dedication. ${ }^{24}$ The religious ceremony was the first non-military act to take place within the walls of the conquered city.

The Christian consecration of mosques made use of typological features of the buildings, such as their spatial orientation. As the mosques in this region typically face Mecca to the East or East-Southeast, their adaptation to Christian purposes posed little difficulties. In order to convert it into the new main altar, the mihrab (the niche marking the qibla wall) was substituted with a cross or a Christian statue. Thus, the orientation towards the East required for Christian temples was maintained without major adjustments. Another straightforward yet equally charged form of appropriation was the adoption of the minaret as bell tower. Other transformations implied more radical shifts in spatial organisation, such as the reorientation of the naves parallel and perpendicular to the qibla of mosques, in order to generate the plan and section of a basilica with a clearly defined central axis focused on the altar. While the building at first preserved its box-like appearance, covered with a monotonous rhythm of consecutive scissor roofs and containing an undifferentiated grid of pillars and juxtaposed aisles, now it was being reorganised around the central aisle, which became the main nave of the new Christian church. The wide dissemination of the model of the Umayyad mosque of Damascus in the western Mediterranean favoured such an amendment. For example, in Ceuta, the central aisle of the mosque was already larger than the others, facilitating the transformation into a Christian church. Raising the height of this central nave would definitely help it to attain the global morphological model of a basilica. Finally, the new faith was broadcasted publicly on the main façade.

This strategy of transformation was adopted in all conquered cities along the coast, regardless of the status of city or town. Some places, where mosques would be consecrated as cathedrals with a residing bishop, could be then called a cidade (city), headquarters of a diocese. Vila (town) would be the denomination for parishes established around a church. Ceuta, a city, or Qsar es-Seghir, a town, are interesting examples of the transformation of their most important religious buildings. ${ }^{25}$

${ }^{24}$ For details related to the consecration of the Qsar es-Seghir mosque, see Pina, Chronica d'El-Rei D. Affonso V 778 and Góis, Crónica do Príncipe D. João 38.

${ }^{25}$ See Gozalbes Cravioto C., El urbanismo religioso y cultural de Ceuta en la Edad Media (Ceuta: 1995) and Redman C.L. - Bonne J.L., "Qsar es-Seghir (Alcácer Ceguer): 
In the case of Ceuta, the desire to turn the main mosque into a cathedral was expressed soon after the conquest. In perfect accordance with the religious motivations underlying the crossing of the Strait, Aymar Aurillac already had taken pride in the title of Bishop of Morocco with his seat in Ceuta since 1413, well two years before the conquest and he does not seem to have travelled to Africa since. ${ }^{26}$ Although historical descriptions, including Al Ansari's, have caused some confusion about the exact site and scale of Ceuta's medieval mosque, it was located in the southwest sector of the medina, between the kasbah and the southern seashore. This way, it appears in the view of Ceuta in the first volume Braun's Civitates Orbis Terrarum (1572), where it is indicated as 'Templu(m) Summu(m)' [Fig. 1]. The engraving shows how the building has the section of a basilica, extended by side naves, as it was used for the Christian cult in the sixteenth century. Inside, there was a hypostyle hall with 180 columns, as documented by Nicolas Lanckman of Falkenstein, priest and representative of Frederick III of Habsburg, who travelled in D. Leonor's train to the city in November $1451 .{ }^{27}$

By opening a square in front of the cathedral, the main façade acquired dignity and its entrance became a focal point in the urban space. After the first building campaign, no significant architectural alterations were made, and the cathedral remained within the former mosque until the end of the seventeenth century, that is, the entire period of Portuguese occupation. ${ }^{28}$

The mosque of Qsar es-Seghir on the southern coast of the Strait of Gibraltar underwent a similar process of transformation. Since the site was never taken over by Morocco after the Portuguese left in 1550,

a 15th and 16th Century Portuguese Colony in North Africa”, Studia 41-42 (1979) $1-57$.

${ }^{26}$ Jordão L.M., Memória histórica sobre os bispados de Ceuta e Tânger (Lisbon: 1858) 3 .

${ }^{27}$ Brásio, "A primitiva catedral de Ceuta" 66. If one counts five longitudinal naves and seventeen transversal ones, and if one conceives a system of double column, together with the pilasters of the walls, that number is achieved. Gozalbes Cravioto, El urbanismo religioso 93 attempts a reconstitution but suggests that the number of 180 columns can be reached or even exceeded if one takes into account the columns that used to separate the former ablution courts, suggesting that Leonor's priest may not have been entirely accurate.

${ }^{28}$ Pérez del Campo L., "Etapas en la construcción de la catedral de Ceuta", in Ripoll Perelló E. (ed.), Actas del Congreso Internacional "El Estrecho de Gibraltar" 42-43. In 1648, Mascarenhas confirmed this in his description and history of the city of Ceuta: 'La sancta iglesia es de fabrica antiquísima, por qu'antes de ser consagrada al verdadero Dios, avia sido Mesquita', cited in Mascarenhas J., História de la ciudad de Ceuta (1648) (Ceuta - Málaga: 1995) 17. 


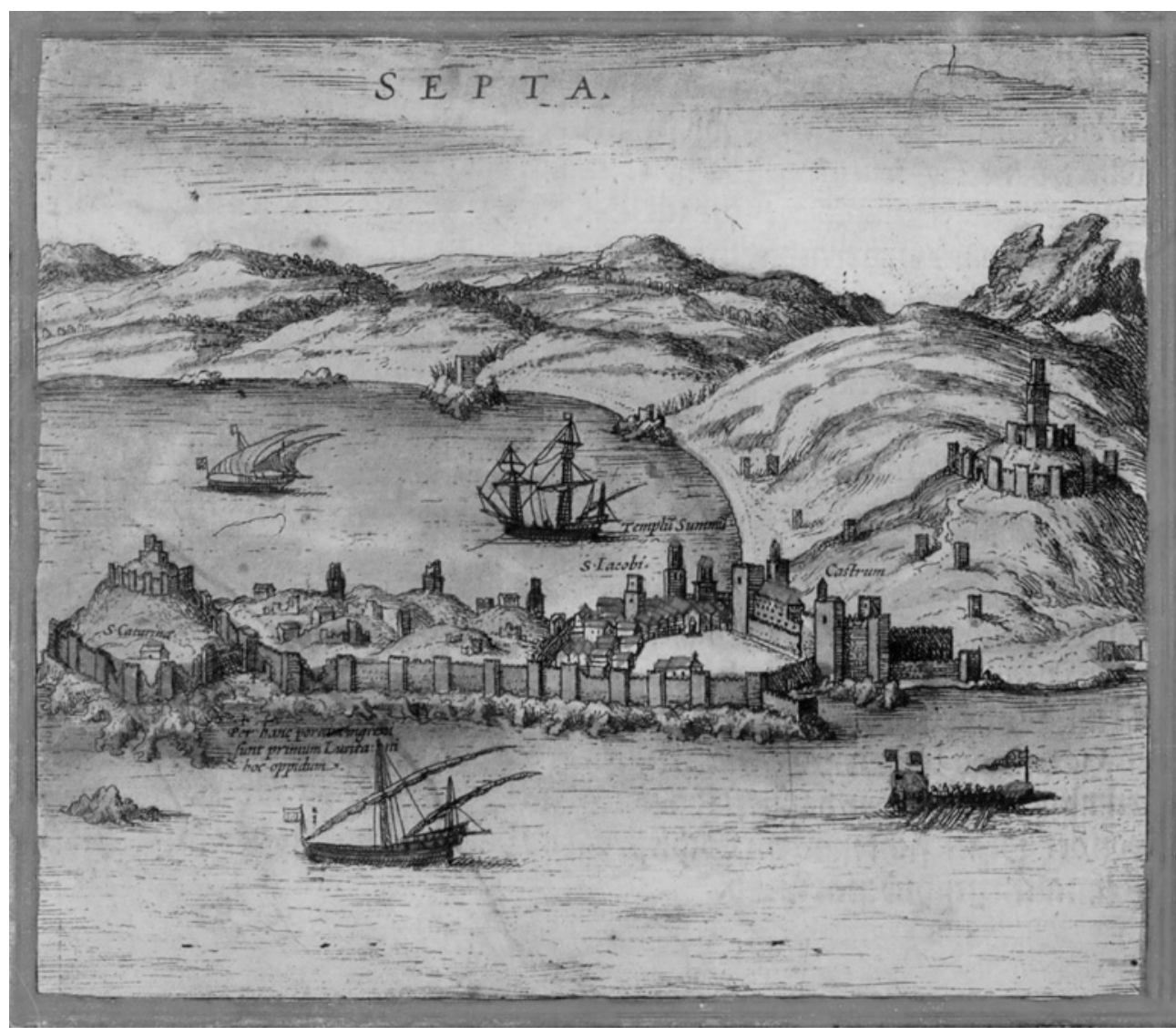

Fig. 1. Septa (Ceuta) in the early sixteenth century, in Braun et alii, Civitates orbis terrarum, 6 vols. (Cologne: 1572) vol. I, fol. 57r.

it is today the only surviving archaeological site in the area with very eloquent Islamic-Portuguese strata [Fig. 2]. After the conquest, the main mosque was immediately turned into the principal church of the town with only minor transformations. ${ }^{29}$ Apart from the evident adjustment of the minaret as a bell tower, the naves retained their

${ }^{29}$ Both Redman - Bonne, "Qsar es-Seghir (Alcácer Ceguer)" 20 and Dias P., A Arquitectura dos Portugueses em Marrocos, 1415-1769 (Coimbra: 2000) 65, identify the main church as Santa Maria da Misericórdia, Our Lady of Mercy. However, ancient chronicles contradict each other. While Pina, Chronica 778 uses this designation, Góis, Crónica 38 notes the dedication of this former mosque to Nossa Senhora da Conceição, Our Lady of Conception. 


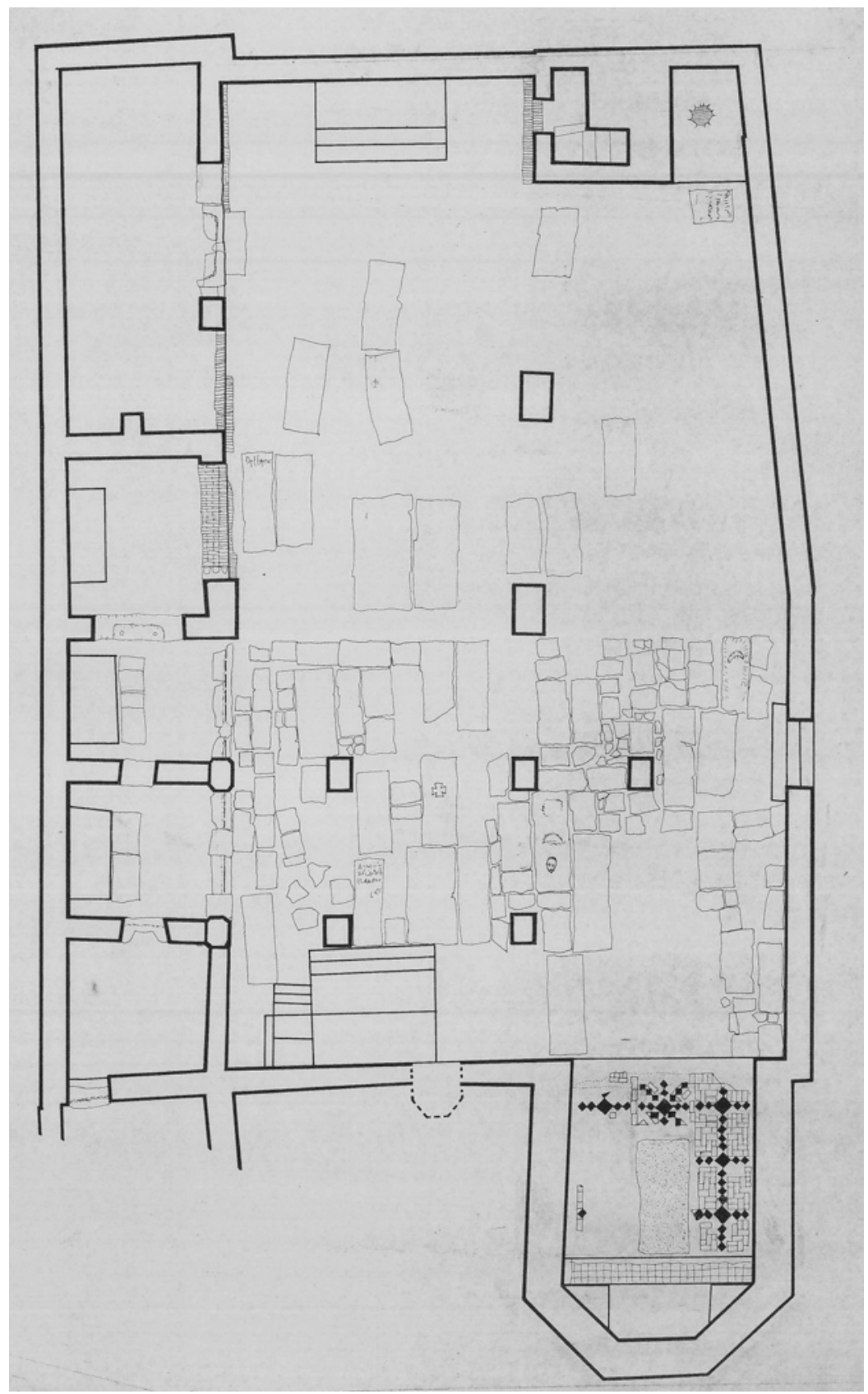

Fig. 2. Qsar es-Seghir. Plan of the ruins of the mosque/church. American Archeological Mission, 1978. Image (C) Inspection des Monuments Historiques, Tangier, Morocco. 
original orientation; at the end of the nave, next to the old mihrab, an eccentric pentagonal main chapel was added. On the southeast wall, side altars were housed in small painted chapels. ${ }^{30}$

The Christian dedication of mosques was indeed among the most important symbols of the change of faith brought about by the new crusade. Especially the conquests of the fifteenth century in the north illustrate the importance of consecrating the conquered spaces in order to establish the Portuguese crown. In fact, the patron saint of Ceuta was Our Lady of Africa. All governors asked for the blessing of this cult image when they arrived in or departed from the city; and during their absence, the city baton was left in her hands. The image still fulfils its protective role today, now for the chief of police of the Spanish enclave.

For the settlements further south, where suzerainty pacts were widespread, commercial interests were more important than the crusading agenda, The main concern of these settlements was indeed to draw profit from Saharan caravans, which, through Marrakesh, would arrive at the nearest Atlantic ports to trade their goods. As soon as political jurisdiction was achieved, however, similar dedication ceremonies took place. Nevertheless, the substitution of Christian symbols in the urban fabric of a Muslim region went far beyond the dedication ceremonies. This essay wishes to look for the effective clashes of power that a European Christian kingdom imposed over a Muslim region. ${ }^{31}$ Churches and cathedrals were created out of mosques, and European castles effaced Muslim kasbahs in order to recreate a new image of the city, reshaping the visual rhetoric of the cityscape.

\section{Urban (Re)foundations}

A fundamental source for the views of cities in the early modern period, Braun's Civitates orbis terrarum, also includes a view on Portuguese Tangier [Fig. 3]. ${ }^{32}$ The most important architectural intervention

\footnotetext{
${ }^{30}$ Detailed information on the decoration and surfaces of the interior of the church can be found in Redman - Boone, "Qsar es-Seghir (Alcácer Ceguer)" 20-22.

${ }^{31}$ Correia J., Implantation de la ville portugaise en Afrique du Nord: de la prise de Ceuta jusqu'au milieu du XVI siècle (Porto: 2008).

${ }^{32}$ Georg Braun - Frans Hogenberg- Simon Novellanus, Civitates orbis terrarum, 6 vols. (Cologne: Philippus Galleus: 1572) vol. I. As with the other drawings of North
} 


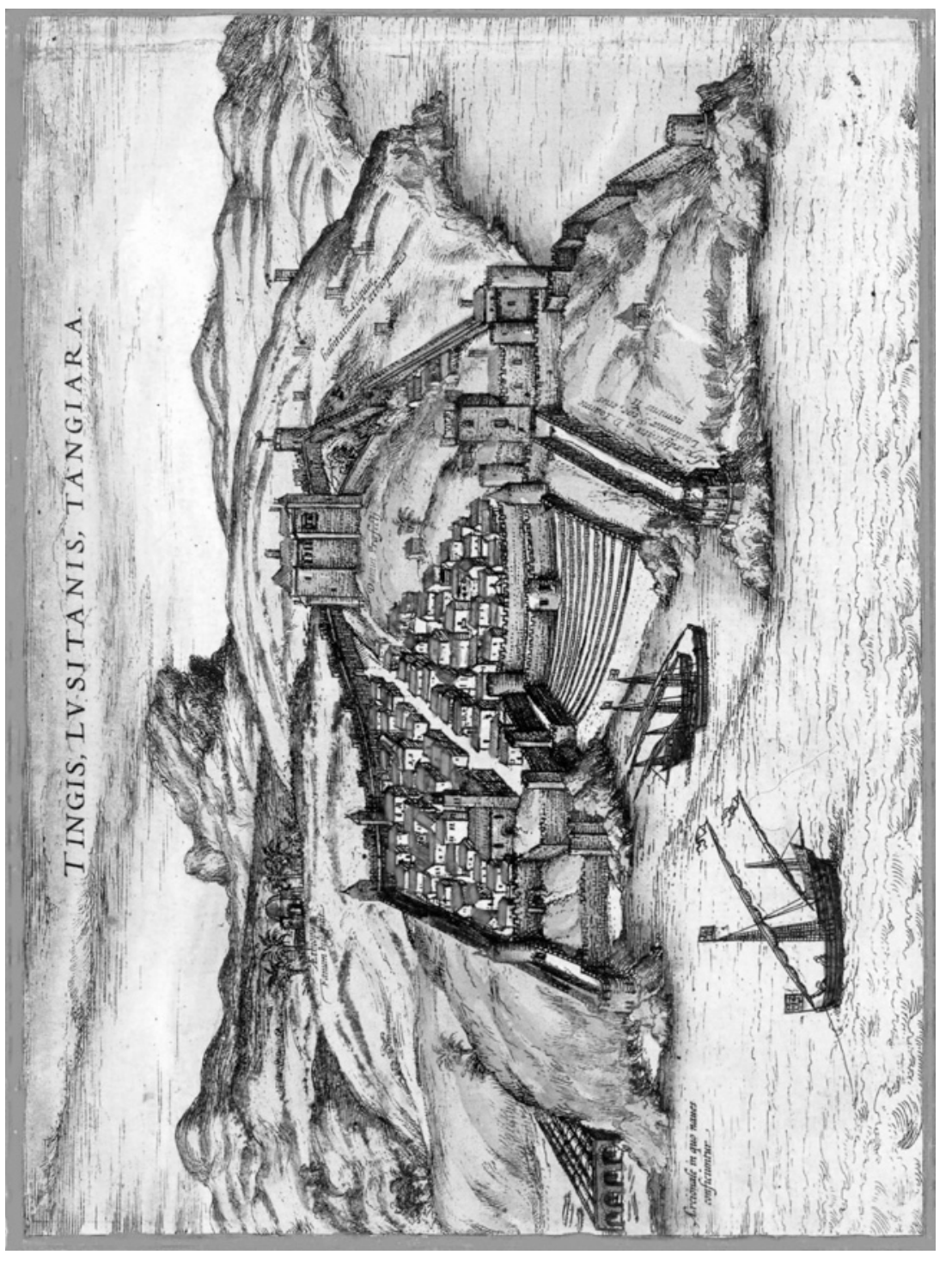

告 
in the new 'emperor's' city was a late-Gothic castle over the kasbah. The building was a tall, compact and towered structure that controlled Tangier from above. Mostly blind at ground level, it was pierced on the first floor and topped by a tiled roof. The new structure implied the demolition of the previous Moorish palace and fortification. In the last quarter of the fifteenth century, Don João II built another castle, Castelo Novo ('New Castle') near the port. This building was erected on a lower level, its main purpose being to protect shipments of provisions from the city in the event of a siege. A square tower crowned by machicoulis with small cylindrical watch-towers in the corners supported a heavily inclined wooden and roof-tiled structure. Both castles employed the latest medieval architectural features seen in Portugal or in territories recently added to the Portuguese crown, and Braun's engraving emphasized them as the two most representative structures of Tangier.

The donjon of the Castelo Novo was typologically similar to the one in Asilah, represented in another view by Braun [Fig. 4]. It was certainly designed and built by Diogo Boytac, who was in Asilah between 1509 and $1510 .^{33}$ It contained a prison on the ground floor, a guardroom on the first floor and was crowned with an audience hall for the governor on the top floor. ${ }^{34}$ From the lavishly decorated window of his office, the governor proclaimed royal orders to the population of Asilah gathered below in the public square.

The architecture of the towers in Tangier and Asilah should be understood in rhetorical terms. After all, the emergence of artillery had rendered their military characteristics obsolete. Their architectural iconography was a discourse of power, broadcasting Christian presence in Africa. The atavistic donjon of Asilah, for instance, is clearly disjointed from the rebuilt bastions and walls, which clearly were built taking into account pre-modern developments in military technology. Today, the donjon still stands as the only remaining medieval tower on the African continent [Fig. 5].

\footnotetext{
African cities (Septa, Arzilla, Sala and Tzaffin), this is an adaptation of an original drawing dating from the beginning of the sixteenth century.

${ }^{33}$ Archivo Histórico Portuguez (Lisbon: 1903-1918) 365: '[...] Mandámos ora tomar a Diego de Alvarenga, cavaleiro da nossa casa, de todo o dinheiro e cousas que recebeo e despendeo nas obras da nossa villa de arzila, os annos de 509 e 510, em pagamento dos soldos da gente que na dita villa serviu, [...]; e 10:000 rs. de mestre Butaqua; [...]'.

34 Arzila, Torre de Menagem [Le donjon d'Asilah] (Lisbon: 1995) 43.
} 


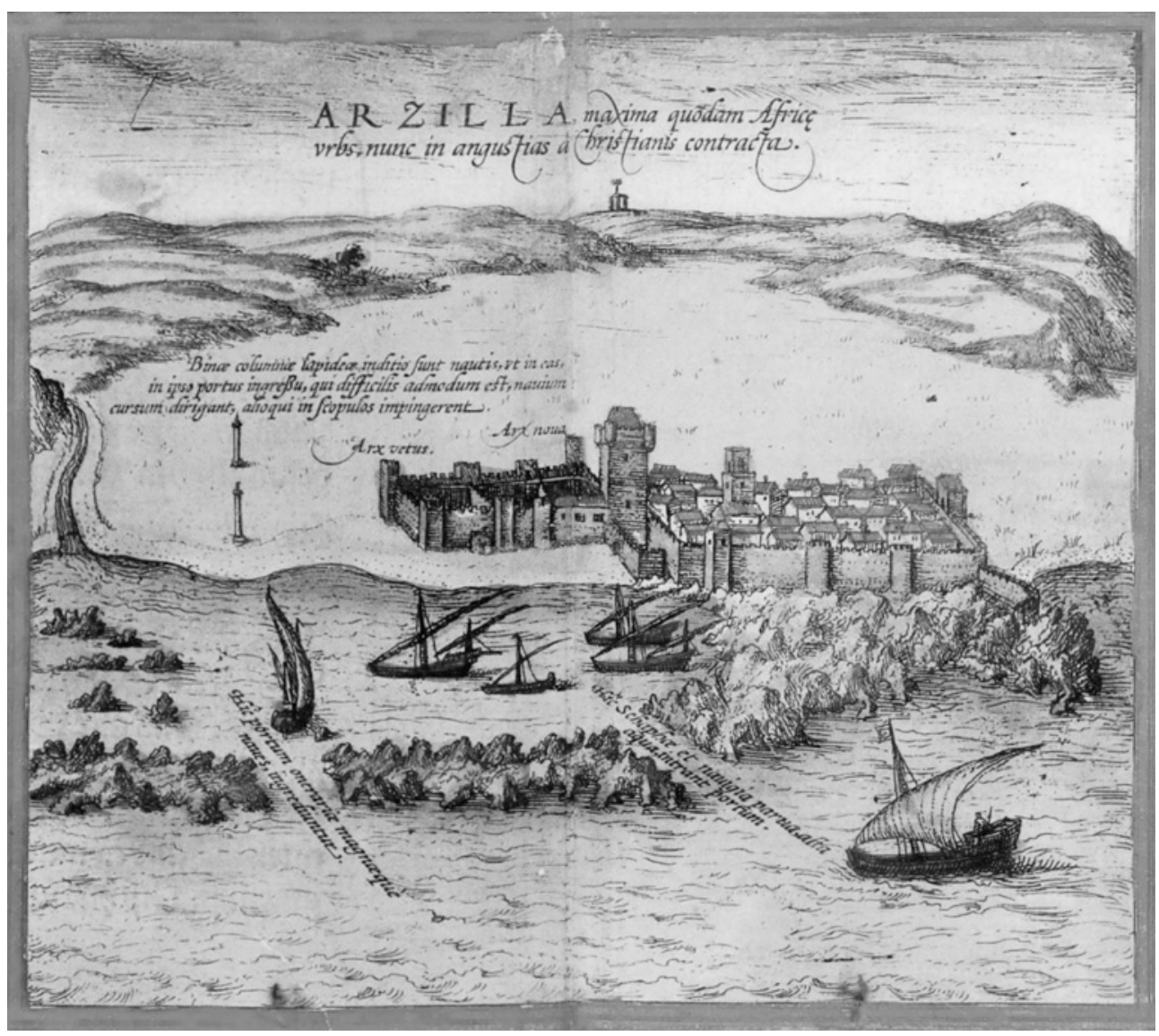

Fig. 4. Arzilla (Asilah) in the early sixteenth century, in Braun et alii, Civitates orbis terrarum, 6 vols. (Cologne: 1572 ) vol. I, fol. $57 \mathrm{r}-57 \mathrm{v}$.

During the first quarter of the sixteenth century and further south, Don Manuel I advocated a similar symbolical style of architecture, despite ongoing military and technological innovations. In a permanently hostile environment, modern bastions were decorated with garlands exhibiting Christian crosses and the Portuguese coats of arms, such as those in Azemmour, where decorative programmes went beyond purely military pragmatism. The festive sight of flags on top of recently fortified bastions, as well as their names, such as S. Cristóvão ('St Christopher') and Raio ('Thunderbolt'), confirm that the Portuguese aimed to emphasize Christian claims on territories beyond the Mediterranean in early modern times [Fig. 6]. In fact, from a military point of view, the large range of fire shot from radial platforms was 


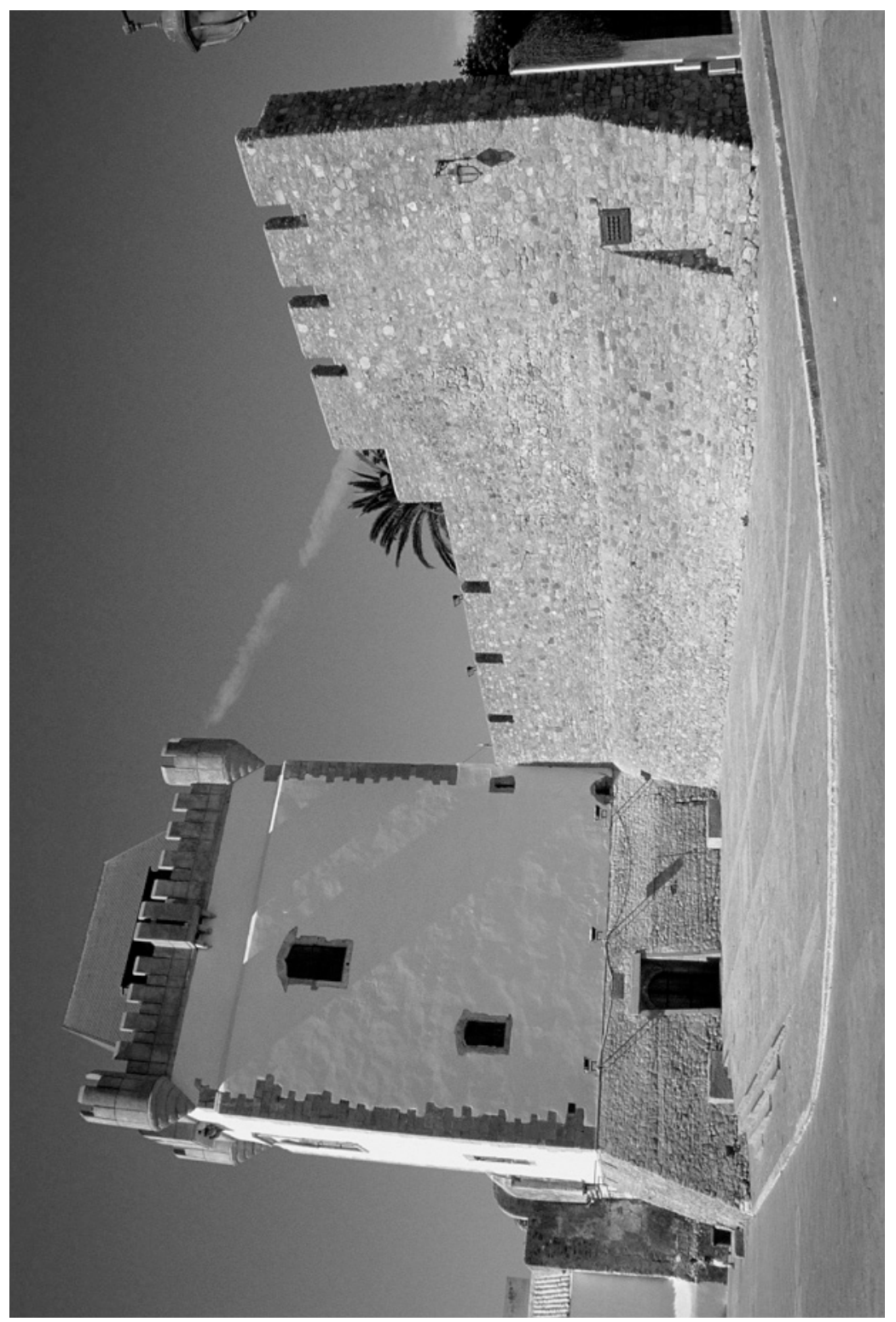

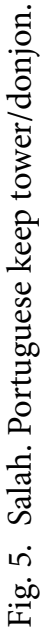




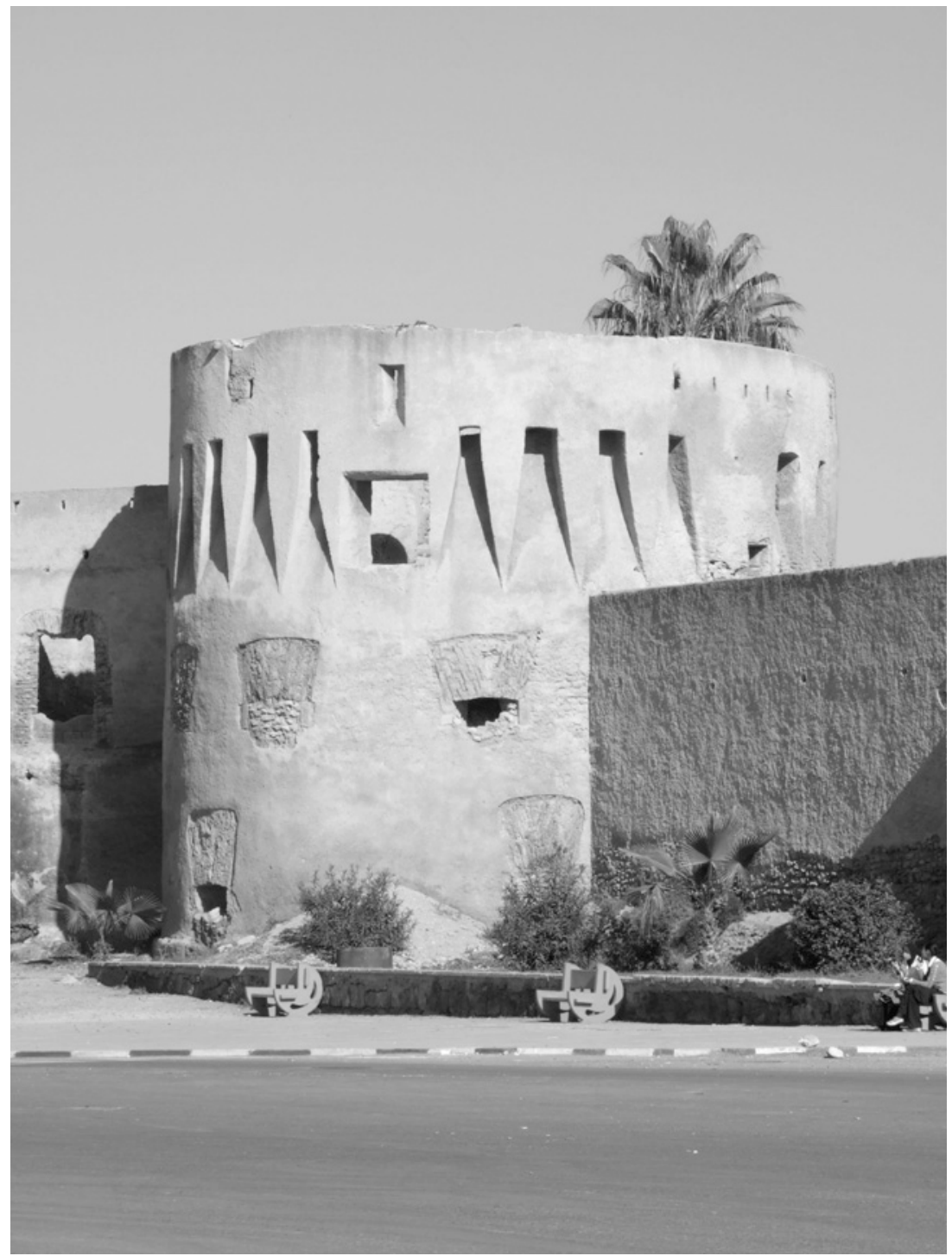

Fig. 6. Azemmour. Bastion of S. Cristóvão [St Christopher]. 
enough to control the hinterland. Hence, the pierced balcony, a reminiscence of close-war techniques of earlier times, decorated with flags (the flagpole holders can still be seen today), reveal the strong message the Portuguese king wished to convey to the local enemy.

Still, Portuguese interventions in their newly founded cities were primarily pragmatic in nature, oriented towards the fortresses' sustainability. To that end, their perimeter and surface were significantly reduced in a procedure known as atalho ('downsizing'). This highly rational technique had important consequences for the appearance of the conquered city, regularizing them geometrically, opening them to the maritime channel and re-evaluating their urban fabric. Today, these interventions are the most tangible remnants of the Portuguese implantation by conquest, implementing regular shapes and figures in the inherited Islamic urban assemblages. Building operations after conquests show a propensity for quadrangular forms, and new walls are often at square angles with pre-existing defensive structures. The Portuguese areas in Ceuta or Azemmour are contained in slightly imperfect geometrical figures, such as rectangles or squares, whereas that of Asilah consists of two rectangles. All decisions display an urgency to rationalize the curved boundary walls of the Islamic medina. The urban design of Ceuta contains yet another distinctive feature - a double atalho - that is encountered in only two other Portuguese 'cidades' in the Maghreb, Tangier and Safi. Since in both cases the topography did not allow for 'rationalization,' a double atalho was applied to change the orientation of the city, cutting through sprawling inland sections and opening the urban space to the harbour [Fig. 7]. New buildings, such as the customs, the exchequer and the mint, marked intensified exchanges between Europe and Northern Africa.

In Safi, a new large bastion on the upper castle again bore witness of both military pragmatism and symbolical intentions. Built in 1540, just one year before the Portuguese would evacuate the Maghreb, the side facing the hinterland and the enemy capital of Marrakech was decorated with the Portuguese coats of arms flanked by armillary spheres [Fig. 8]. Today known as Bordj Dar, the former castle bastion (Baluarte da Alcáçova) was the dernier cri of a city that had failed to dominate Morocco, denying the eve of a new era. If its disproportionate scale achieved one of its main objectives, namely to install fear, it only barely hid its obsoleteness in the face of evolving military technology. The scale of the massive volume compared to the very 


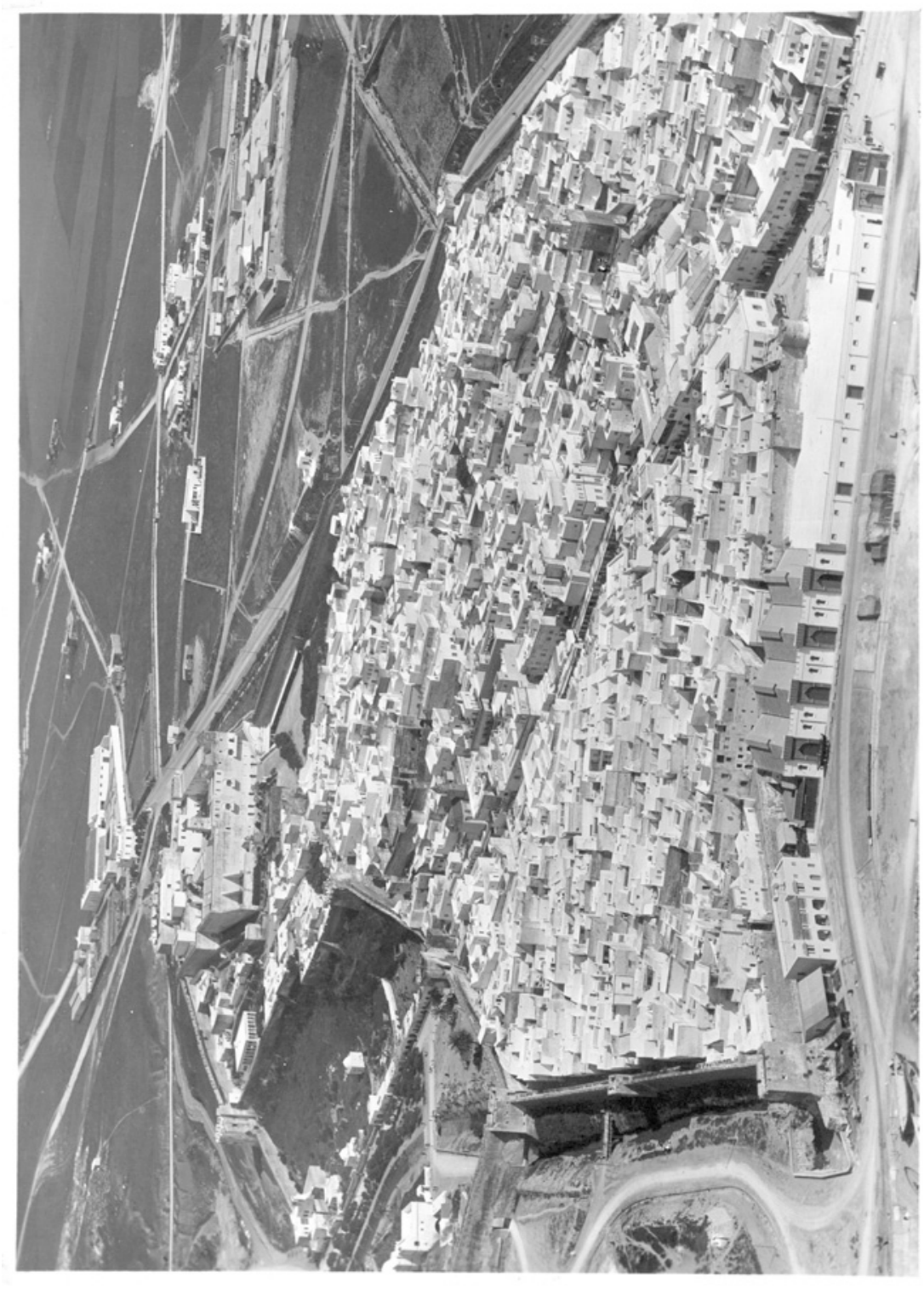

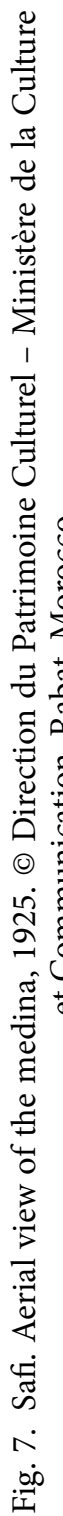




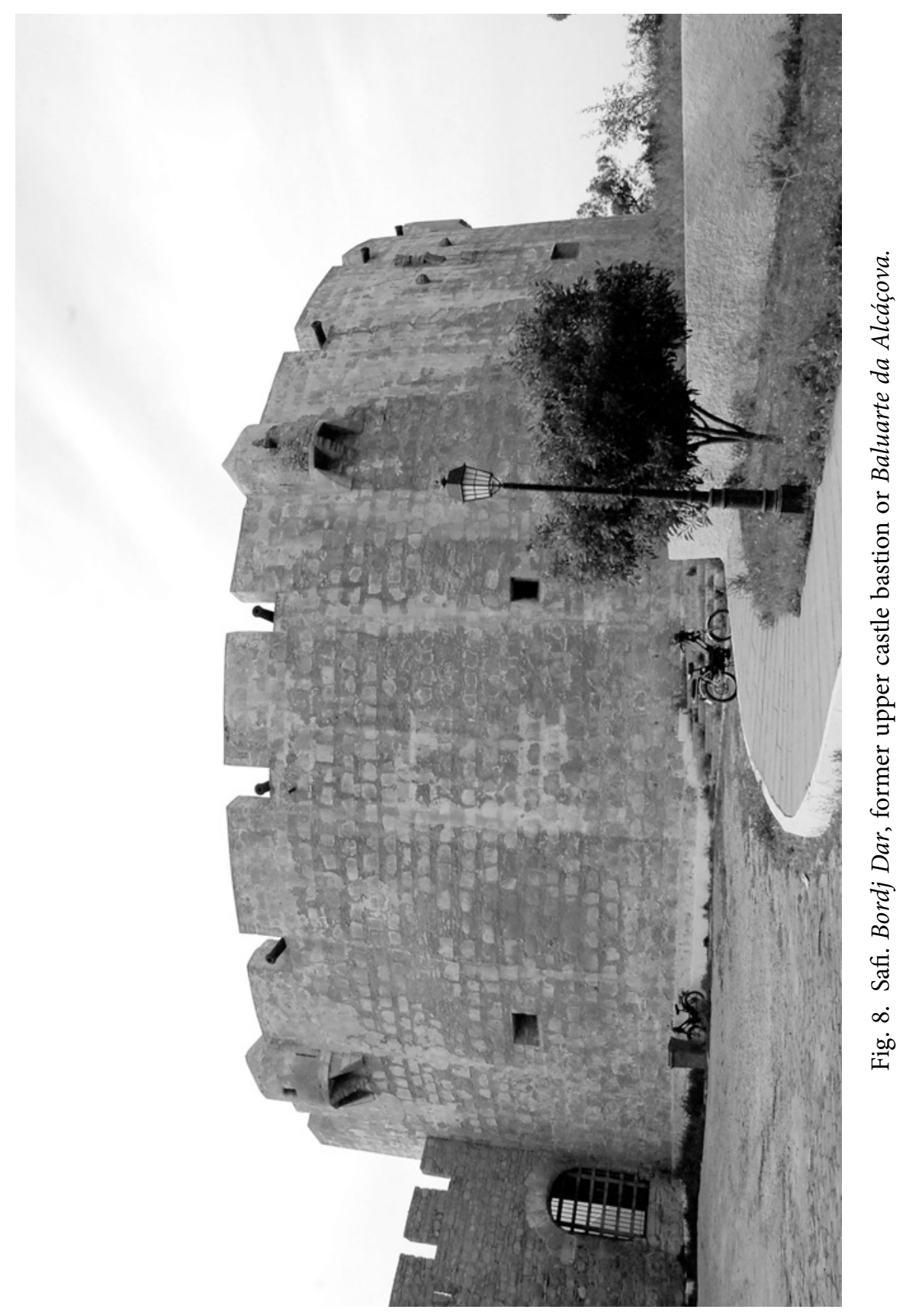


small openings for artillery seems to identify the building as a clear frontier of power and belief. Given that the evacuation of the city was being considered as early as 1534, this last building effort in Safi shows the same (re)foundational spirit that enabled the transformation of the Tangier Kasbah in the previous century. In fact, architecture was used as a distinguished and intentional tool of the 'dedication' of the whole city to a new faith and an inherent visual and social identity in this territory.

In all cases, both military considerations and the creation of public spaces informed a new layout of the pattern of streets. The main street, the rua Direita, now connected the major gates of the town, the sea and the hinterland. Ideal places for meetings, markets or public announcements by the governor, the central squares generated several secondary arteries, which together with the main street tried to form a grid pattern. The inherited urban model was thus rejected and with it, the paradigm of privacy and intimacy that characterizes the traditional Mediterranean urban morphology under Islamic influence. That now was slowly replaced by the public expression of identity by means of façades inherent to European culture. As mentioned above, this process was equally inspired by new developments in Europe, where concerns with hygiene and rationalism led to the development of the late medieval bastides or new towns, whose exportation to Northern Africa asserts the European historical tradition of regularity expansion.

Signs of regular planning are evident in Azemmour and Asilah, geographically close to the pioneering foundation of Mazagão some decades later. Both towns benefited from large empty surfaces. In the case of Azemmour, only the former kasbah and mosque remained as landmarks prone to transformation [Map 4]. Christian Asilah would be reborn from the ashes of the 1508 Moorish assault, whose destruction of the city enabled an almost ex novo foundation. In both cases, the conditions allowed the Portuguese to apply principles of grid planning, mainly by creating long rectangular blocks of similar proportions. Urbanism worked as a powerful instrument of cultural affirmation, obliterating a cultural legacy that was still very present in the southern Iberian Peninsula. This late Reconquest process alerted Portugal to its own medieval condition at the time and nudged the nation towards early modernity. 


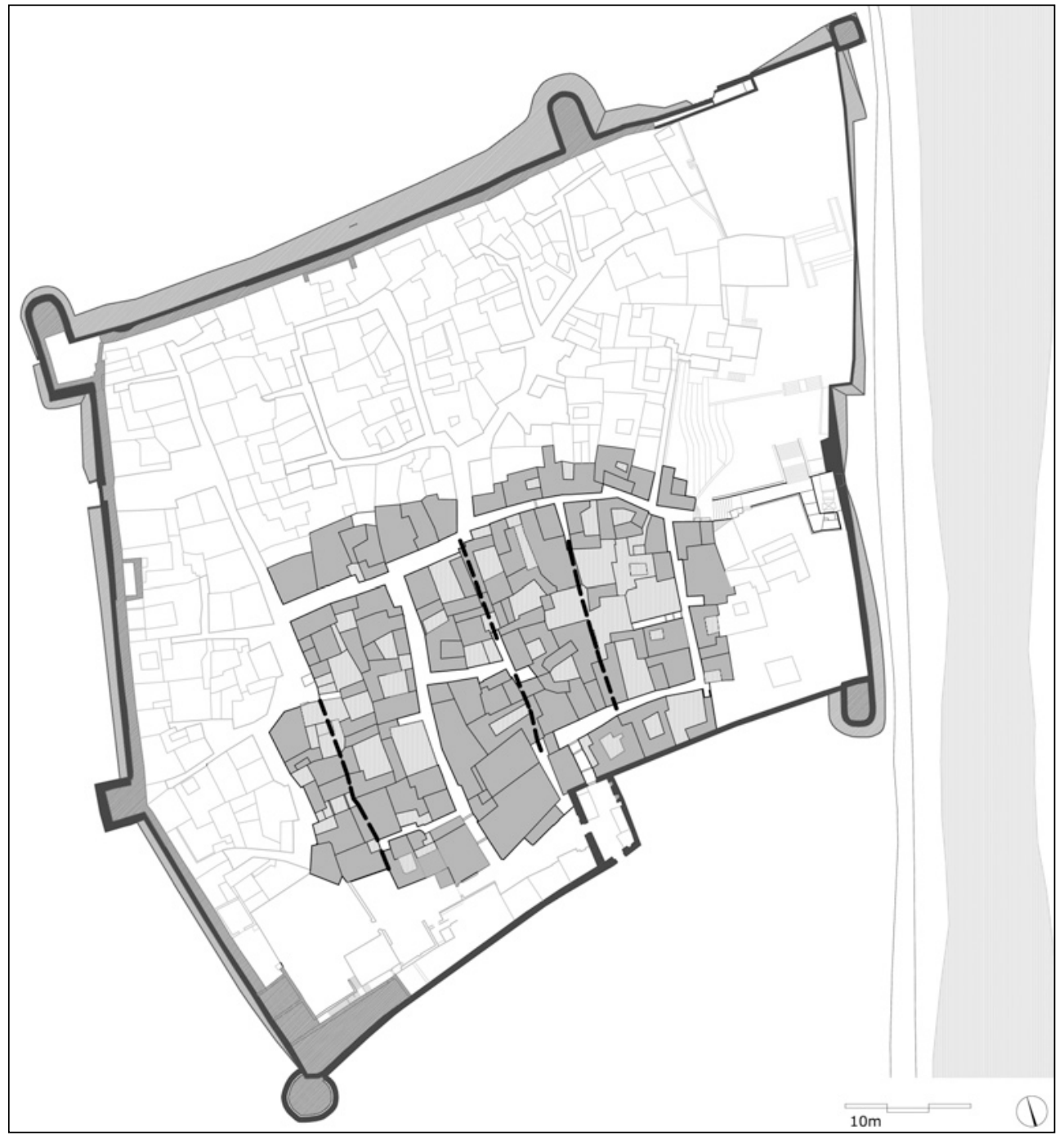

Map 4. Azemmour. Architectural survey of the Kasbah/Mellah quarter with a hypothesis of the Portuguese urban fabric. 


\section{Conclusion}

This paper demonstrates that the (re)foundation of cities as part of the Portuguese realm implied religious, social and military processes. Ceremonies, such as consecration masses or cavalry investitures, occurred together with the physical transformation of the city. '(Re)foundation' involved symbolical behaviour in line with the (re)design of the city's buildings and public space, resulting in a new cityscape. Diachronic encounters between two different concepts and cultures have stressed the instruments of appropriation the Portuguese used in Northwest Africa for the establishment of these enclaves. My argument took into account three main aspects: an inspiration from classical mythology; a noble class that was still clearly medieval in its cavalry approach and warrior impetus; and a pragmatic behaviour that combined survival with rationality.

But perhaps more fundamentally, these processes formed part of a larger notion of political foundation and religious dedication imposed over a hostile and 'unfaithful' land. ${ }^{35}$ Ownership and authority bestowed Don João I, Don Afonso V and later Manuel I with the aura of 'princes of the Renaissance'. The 'classical' origins evoked by the conquests of Ceuta and Tangier would relate them to the emerging humanist culture, while positioning them at the heart of the Christian endeavour. For Portugal, the Maghreb did not represent the discovery or colonisation of a new world; instead, it may have acted as a laboratory for experimental military technology and architecture. Yet, definitely, it represented the irreversible emergence of ideas related to the early modern state.

\footnotetext{
${ }^{35}$ From the long bibliography on this subject, see Peres D. (ed.), História de Portugal, 8 vols. (Barcelos: 1928-1954) vol. III, chapters 3-5; part II of Braga - Braga, Ceuta Portuguesa and Oliveira Marques, Nova História da Expansão Portuguesa.
} 


\section{Selective Bibliography}

Al ANSARI, "La physionomie monumentale de Ceuta: un hommage nostalgique à la ville par un de ses fils, Muhammad B. Al-Qasim Al Ansari", Hespéris-Tamuda 20-21 (1982-1983) 113-162.

Archivo Histórico Portuguez, 11 vols. (Lisbon: 1903-1918).

Arzila, Torre de Menagem [Le donjon d'Asilah] (Lisbon: 1995).

Baeza Herratzi A., "La Fundación de Ceuta y la Fábula de Noé", in Ripoll Perelló E. (ed.), Actas del Congreso Internacional "El Estrecho de Gibraltar" (Ceuta: 1987 Madrid: 1988) vol. II, 673-678.

Bethencourt F. - Chaudhuri K. (eds.), História da Expansão portuguesa, 5 vols. (Lisbon: 1998).

Boxer C.R., O Império Marítimo Português, 1415-1825, trsl. I. Silva (Lisbon: 2001).

Braga I.D. - Braga P.D., Ceuta Portuguesa 1415-1656 (Ceuta: 1998).

Braun Georg - Hogenberg Franz - Novellanus Simon, Civitates orbis terrarum, 6 vols. (Cologne, Philippus Galleus: 1572).

Brásio A., "A primitiva catedral de Ceuta", in História e Missiologia. Inéditos e esparsos (Luanda: 1973) 56-83.

CÉnival P., Les Sources Inédites de l'Histoire du Maroc. Première Série - Dynastie Sa'dienne, Archives et Bibliothèques de Portugal, 2 vols. (Paris: 1934-1946).

CORREIA J., Implantation de la ville portugaise en Afrique du Nord: de la prise de Ceuta jusqu'au milieu du XVI siècle (Porto: 2008).

Dias P., A Arquitectura dos Portugueses em Marrocos, 1415-1769 (Coimbra: 2000).

Farinha A.D., Portugal e Marrocos no séc. XV, 3 vols. (Lisbon, 1990).

Góis Damião De, Crónica do Príncipe D. João, ed. G.A. Rodrigues (Lisbon: 1977).

Gozalbes Cravioto C., El urbanismo religioso y cultural de Ceuta en la Edad Media (Ceuta: 1995).

Guevara A.L., Arcila durante la ocupación Portuguesa (1471-1549) (Tanger: 1940).

JoRDÃo L.M., Memória histórica sobre os bispados de Ceuta e Tânger (Lisbon: 1858).

Livro dos Arautos = De Ministerio Armorum, ed. A.A. do Nascimento (Lisbon: 1977).

Mascarenhas Jeronymo de, História de la ciudad de Ceuta (1648) (Ceuta - Málaga: 1995).

Metalsi M. - Tréal C. - Ruiz J.-M., Les villes impériales du Maroc (Paris: 1999).

Moreira R. (ed.), História das Fortificações Portuguesas no Mundo (Lisbon: 1989).

Oliveira Marques A.H. (ed.), Nova História da Expansão Portuguesa. A Expansão Quatrocentista 2 vols. (Lisbon: 1998).

Peres D. (ed.), História de Portugal, 9 vols. (Barcelos: 1928-1954).

Perez Del Campo L., "Etapas en la construcción de la catedral de Ceuta", in Ripoll Perelló, E. (ed.), Actas del Congreso Internacional "El Estrecho de Gibraltar" (Ceuta: 1987 - Madrid: 1988) 41-50.

Pina Rui De, Chronica d'El-Rei D. Affonso V (Lisboa: 1901).

Redman C.L. - Bonne J.L., "Qsar es-Seghir (Alcácer Ceguer): a 15th- and 16th-Century Portuguese Colony in North Africa", Studia 41-42 (1979) 1-57.

Ricard R., Les Sources Inédites de l'Histoire du Maroc. Première Série - Dynastie Sa'dienne, Archives et Bibliothèques de Portugal, 5 vols. (Paris: 1948-1951).

- Études sur l'histoire des portugais au Maroc (Coimbra: 1955).

Torres Balbas L., Ciudades hispano-musulmanas, 2 vols. (Madrid: 1985).

Zurara Gomes Eanes De, Chronica de El-Rei D. João I, 3 vols. (Lisbon: 18991900).

_, Crónica da tomada de Ceuta, ed. F.M.E. Pereira (Lisbon: 1915).

—, Crónica da Tomada de Ceuta, ed. A. Pimenta (Lisbon: 1942).

—, Crónica do Conde D. Duarte de Meneses, ed. L. King (Lisbon: 1978). 